\title{
Comparison on Nursing Undergraduates' Mastery of 2015 Edition Cardiopulmonary Resuscitation Skills in Terms of Different Student Sources
}

\author{
Taotao Zhang ${ }^{1}$, Yunfei Li ${ }^{2}$, Li Sun ${ }^{1}$ \\ ${ }^{1}$ School of Nursing, Hubei University of Medicine, Shiyan, Hubei Province, China. \\ ${ }^{2}$ Department of Urological Surgery, Shiyan Renmin Hospital Affiliated to Hubei University of Medicine, \\ Shiyan, Hubei Province, China.
}

Keywords: Source of Students; Nursing Undergraduates; Cardiopulmonary Resuscitation.

\begin{abstract}
Through comparing students' scores in theory and operation tests of 2015 edition CPR procedure, this paper studies the differences in nursing undergraduates' mastery of CPR skills in terms of student source, and provides basis for the formulation of teaching strategies according to features of diversified students in the future. Research objects in this paper are nursing students enrolled in Hubei University of Medicine in 2015. Among them, 27 students come from second-grade colleges, 24 come from third-grade colleges, 30 from secondary vocational schools. 2015 edition of CPR is taught in the course of Basic Nursing under the same teaching conditions. The differences in nursing undergraduates' scores in theory and operation tests are compared and analyzed from the perspective of student source. Results show that there are no significant statistical differences between the theory and operation test scores of second-grade colleges students and third-grade college students $(\mathrm{P}<0.01)$. Compared with second-grade and third-grade college students, nursing students from secondary vocational schools show significant differences statistically in theory and operation test results, as well as the accuracy of chest compression and airway open $(\mathrm{P}<0.05)$. Therefore, it is necessary to adopt diversified teaching methods according to different characteristics of students. Teachers need to strengthen vocational training for second-grade and third-grade college students to improve their theoretical and practical abilities. For students from secondary vocational school who have formed certain foundations of CPR, simulation teaching mode could be adopted to improve their comprehensive abilities in analyzing and solving problems.
\end{abstract}

\section{Introduction}

At present, the student source of nursing undergraduates in our school can be grouped into second-grade colleges, third-grade colleges and secondary vocational schools. Students come from different kinds of schools are distributed to different classes. The mastery of cardiopulmonary resuscitation (CPR) skills is one of the keys and difficult points in the Basic Nursing course. As a kind of emergency treatment, a series of assessment and intervening measures are included in CPR. Nurses' CPR skills are closely related to the morbidity and mortality of patients. [1] On October 15, 2015, the 2015 American Heart Association Guidelines Update for Cardiopulmonary Resuscitation and Emergency Cardiovascular Care was published online. The journal of Circulation and Resuscitation magazine also published this article. Through comparing students' scores in theory and operation tests of 2015 edition CPR procedure, this paper studies the differences in nursing undergraduates' mastery of CPR skills in terms of student source, and provide basis for the formulation of teaching strategies according to features of diversified students in the future.

\section{Research Objects and Methods}

Teaching objects and grouping: research objects in this paper are nursing students enrolled in our school at 2015. Among them, 27 students come from second-grade colleges, 24 students come from third-grade colleges, and 30 students come from secondary vocational schools. There are no significant differences on age and gender of three groups of students $(\mathrm{P}>0.05)$. 
Teaching method: in this research, theory learning lasts for 2 periods; operation teaching lasts for 3 periods. Teachers conduct operation assessment for all students in the last 1 period through the unified scoring criteria.

Teaching organization method: three groups of students need to learn the course of Basic Nursing at the first semester of the second year. The theory content and operation procedure of manual CPR is taught by the same teacher; theory and practice teaching cost 2 periods and 3 periods respectively. The theory and operation standards are made according to the 2015 American Heart Association Guidelines Update for Cardiopulmonary Resuscitation and Emergency Cardiovascular Care. Several links included in the teaching process are instructing, case analysis, video observation, simulation exercises and assessment.

According to 2015 American Heart Association Guidelines Update for Cardiopulmonary Resuscitation and Emergency Cardiovascular Care, unified theoretical examination paper and operation assessment scale which can cover the key points of basic knowledge and operation skills are made. The full score is 100 . The theory assessment is made up of 20 objective questions. The operation duration is 5 minutes. In order to improve the accuracy of the record, 2 recorders are arranged. They need to simultaneously record the time duration of 30 chest compressions, aspiration in the artificial respiration, judgment consciousness and carotid pulse in 5 cycles by a stopwatch.

Statistical analysis is carried out by using SPSS 17.0 software. Data are analyzed through variance analysis F test. LSD method is adopted in paired-comparison between any two groups. Counting data are expressed in percentage (\%). $\chi^{2}$ test is used to compare data among groups. The significant level $\alpha=0.05$.

\section{Research Results}

Three group nursing students' scores in theory and operation tests can be seen from Table 1 and Table 2. Compared with students from second-grade colleges and secondary vocational schools, the theory test scores of third-grade college students show statistically significant difference $(\mathrm{P}<0.05)$. There's no statistical significant difference between the theory test scores of second-grade colleges students and secondary vocational school students $(\mathrm{P}>0.05)$. Compared with second-grade and third-grade college students, the operation test results of nursing students from secondary vocational schools show statistically significant difference $(\mathrm{P}<0.01)$. There's no statistical significant difference between the operation test scores of second-grade colleges students and third-grade college students $(\mathrm{P}>0.05)$.

Table 1. Theory and operation test scores of students from three groups

\begin{tabular}{cccc}
\hline group & case & Theory test score & Operation test score \\
\hline Second-grade college & 27 & $90.74 \pm 9.12$ & $80.37 \pm 7.57$ \\
third- grade college & 24 & $81.77 \pm 16.88$ & $78.29 \pm 6.84$ \\
Secondary vocational school & 30 & $91.25 \pm 8.92$ & $91.43 \pm 4.26$ \\
F & & 3.860 & 34.169 \\
P & & $0.025^{*}$ & $0.000^{* *}$ \\
\hline
\end{tabular}

Note: $* \mathrm{P}<0.05, * * \mathrm{P}<0.01$

Table 2. Paired-comparisons of theory and operation test scores of students from three groups

(Pvalue)

\begin{tabular}{ccc}
\hline group & Theory test score & Operation test score \\
\hline Second and third grade college & $0.022^{*}$ & 0.250 \\
Second-grade college and & 0.889 & $0.000^{* *}$ \\
secondary vocational school & & $0.000^{* *}$ \\
Third -grade college and & $0.013^{*}$ & \\
secondary vocational school & & s.
\end{tabular}

The comparison of operation accuracy is shown in Table 3. There are statistically significant differences in the accuracy of chest compression and airway open between students from secondary 
vocational schools and students from third-grade and second-grade colleges $(\mathrm{P}<0.05)$.

Table 3. Comparison of operation accuracy (n, \%)

\begin{tabular}{|c|c|c|c|c|c|}
\hline Item & $\begin{array}{l}\text { Second-grade } \\
\text { college }\end{array}$ & $\begin{array}{l}\text { Third- grade } \\
\text { college }\end{array}$ & $\begin{array}{l}\text { Secondary } \\
\text { vocational school }\end{array}$ & $\chi^{2}$ & $\mathrm{P}$ \\
\hline consciousness assessment & $20(74.1 \%)$ & $20(83.3 \%)$ & $29(96.7 \%)$ & 5.840 & 0.054 \\
\hline carotid pulsation assessment & $22(81.4 \%)$ & $21(87.5 \%)$ & $30(100 \%)$ & 5.739 & 0.057 \\
\hline $\begin{array}{l}\text { Location of chest compression } \\
\text { (average of } 5 \text { times) }\end{array}$ & $18(66.7 \%)$ & $15(62.5 \%)$ & $27(90 \%)$ & 6.408 & $0.041^{*}$ \\
\hline $\begin{array}{l}\text { frequency of chest compression } \\
\text { (average of } 5 \text { times) }\end{array}$ & $17(62.9 \%)$ & $17(70.8 \%)$ & $28(93.3 \%)$ & 7.920 & $0.019 *$ \\
\hline $\begin{array}{l}\text { depth of chest compression } \\
\text { (average of } 5 \text { times) }\end{array}$ & $20(74.1 \%)$ & $18(75 \%)$ & $29(96.7 \%)$ & 6.494 & $0.039 *$ \\
\hline $\begin{array}{l}\text { Effective airway open(average of } \\
2 \text { times) }\end{array}$ & $21(77.8 \%)$ & $20(83.3 \%)$ & $30(100 \%)$ & 7.073 & $0.029 *$ \\
\hline $\begin{array}{l}\text { Effective artificial ventilation } \\
\text { (average of } 2 \text { times) }\end{array}$ & $18(66.7 \%)$ & $16(66.7 \%)$ & $27(90 \%)$ & 5.531 & 0.063 \\
\hline
\end{tabular}

Note: $* \mathrm{P}<0.05, * * \mathrm{P}<0.01$

\section{Discussions}

\subsection{Analyses of theory test scores and improvement measures}

Some scholars point out that, students who have received high school education and passed the college entrance examinations are more open-minded; they have solid basis on cultural knowledge, as well as strong learning abilities and adaptability. Vocational school students do not attend high school, and are lack of basic knowledge. [2] But the results of this study show that, there's no statistical significant difference between the theory test scores of second-grade college students and secondary vocational school students. It might be due to this study only focuses on cardiopulmonary resuscitation. Students from secondary vocational schools have learned the content of CPR and form the theoretical basis. When learning the 2015 edition CPR, they only need to grasp modified contents. Though the educational levels of students from second-grade and third-grade colleges are the same, their scores in the college entrance examination are different. Students' comprehensive qualities, independent learning abilities and class atmosphere vary, too [3]. These differences lead to the difference in their academic achievements. How to teach the course of Basic Nursing on the basis of students' different situations is a problem which attracts the attention of many experts and professional teachers [4].

Different teaching strategies can be formulated according to different features of students. For instance, second-grade college students are open-minded and have solid theoretical basis. PBL teaching method can be adopted to enhance their abilities to analyze questions and applying knowledge. For third-grade college students, the lively and interesting multimedia teaching can be properly used. Pictures, animation and video can fully arouse their learning enthusiasm, and strengthen the key and difficult points in simple words. For vocational school students who have formed theoretical basis, flipped classroom teaching mode can be applied. Teachers can provide teaching videos as the main form of learning resource; students need to watch and learn these videos before class. In the classroom, teachers and students can carry out activities like question-answering, collaborative inquiry and interactive communication. [5] In these ways, teachers do not need to instill students with monotonous knowledge through repetition. The initiative and enthusiasm of students can be stimulated.

\subsection{Analyses of operation test scores and operation accuracy, and improvement measures}

As it can be found from Table 2, there's statistically significant difference in operation test results of nursing students from secondary vocational schools and students from second-grade and third-grade colleges $(\mathrm{P}<0.01)$. There's no statistical significant difference between the operation test 
scores of second-grade college students and third-grade college students ( $\mathrm{P}>0.05)$.

The accuracy of each step in the operation of single-handed manual cardiopulmonary resuscitation directly affects the quality and effect of CPR. From Table 3, it can be seen that there are statistically significant differences in the accuracy of chest compression and airway open between students from secondary vocational schools and students from third-grade and second-grade colleges $(P<0.05)$.

\section{Conclusions}

In terms of theory test, second-grade college nursing students and secondary vocational school students are superior to third-grade college students. As of the operational quality, students from secondary vocational schools are better than other students. One possible reason is that secondary vocational school students have leant relevant contents before. Hence, in the future, teachers should pay more attention to the theoretical basis of third-grade college students, and improve their comprehensive abilities to analyze and solve problems. Meanwhile, practical ability training should be empathized for second-grade college nursing students through measures like increasing the periods of extra-curricular autonomic learning, so as to improve the overall teaching effects.

\section{References}

[1] H.F. Lu, X.L. Wang, L. Liu, et al., Application of cooperative learning theory in cardiopulmonary resuscitation training for nurses, J. Chinese Nursing Management. 11 (2011).

[2] J.M. Chen, Status of domestic nursing clinical teaching methods, J. Journal of Nursing Science. 18 (2003).

[3] H.F. Guo, Research on the status and influencing factors of humanistic care of nursing students, Dalian Medical University, 2014.

[4] S.Y. Wang, H.P. Rao, J.J. Wu, et al., Comparative analysis and research on the examination results of different basic nursing skills of students from different source, J. China Higher Medical Education. 8 (2014).

[5] X.L. Zhong, S.Q. Song, L.Z. Jiao, Research on instructional design on the basis of flipped classroom concept in the information environment, J. Open Education Research. 19 (2013). 